
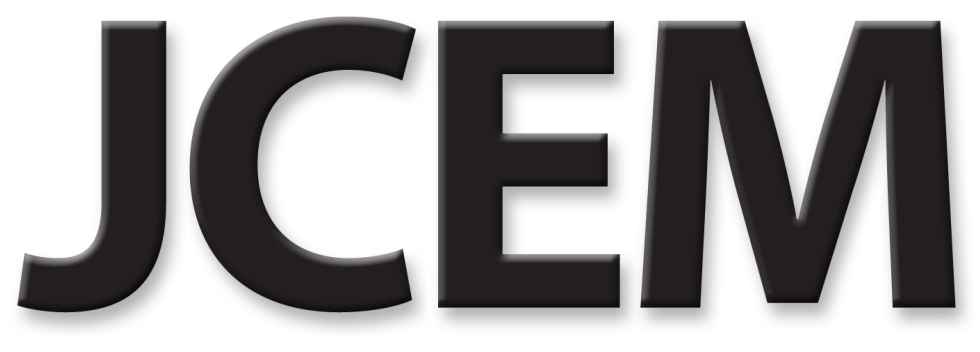

\title{
Pituitary Disease in MEN Type 1 (MEN1): Data from the France-Belgium MEN1 Multicenter Study
}

Bruno Vergès, Françoise Boureille, Pierre Goudet, Arnaud Murat, Albert Beckers, Geneviève Sassolas, Patrick Cougard, Béatrice Chambe, Corinne Montvernay and Alain Calender

J. Clin. Endocrinol. Metab. 2002 87: 457-465, doi: 10.1210/jc.87.2.457

To subscribe to Journal of Clinical Endocrinology \& Metabolism or any of the other journals published by The Endocrine Society please go to: http://jcem.endojournals.org//subscriptions/
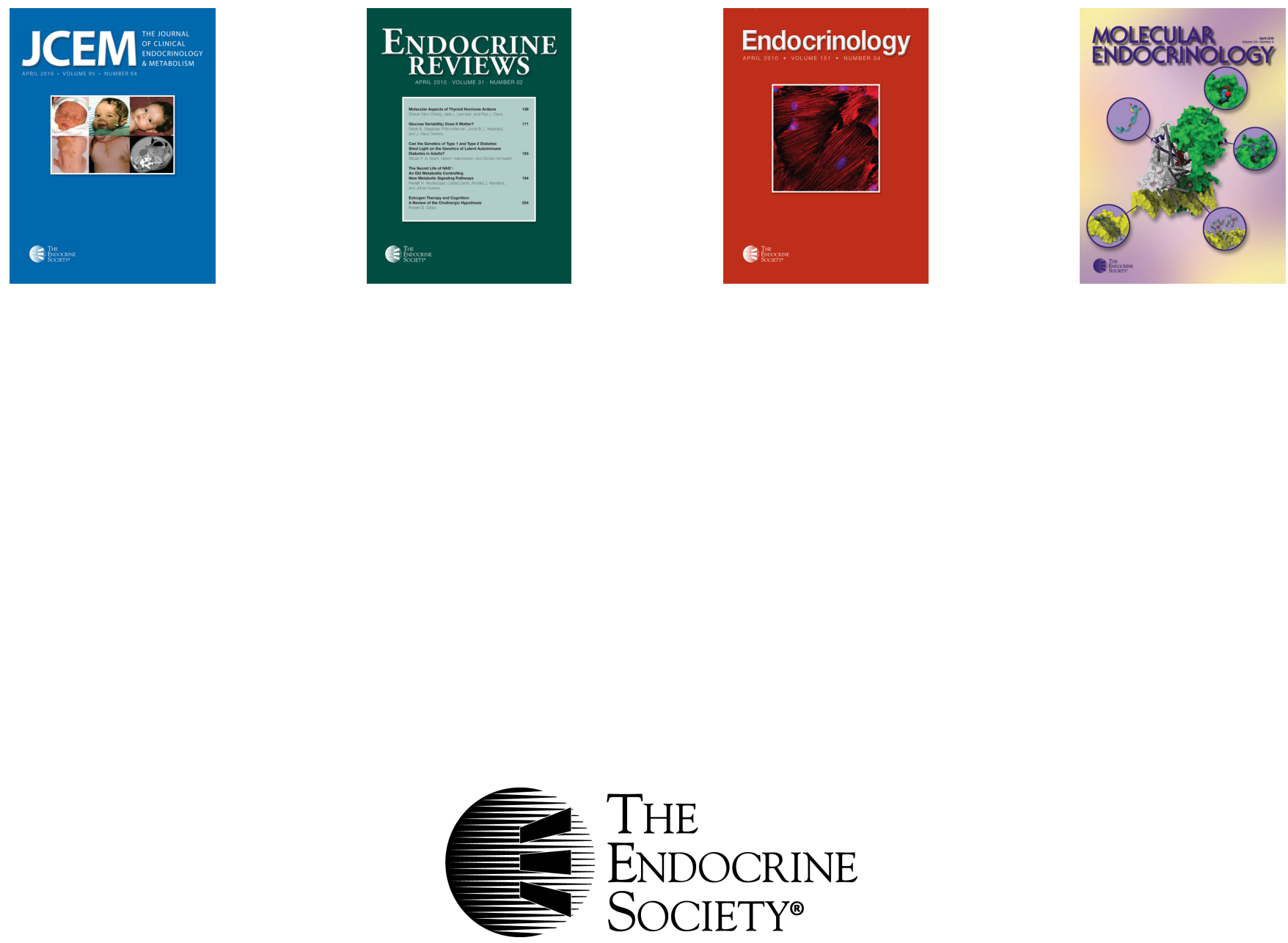


\title{
Pituitary Disease in MEN Type 1 (MEN1): Data from the France-Belgium MEN1 Multicenter Study
}

\author{
BRUNO VERGÈS, FRANÇOISE BOUREILLE, PIERRE GOUDET, ARNAUD MURAT, \\ ALBERT BECKERS, GENEVIÈVE SASSOLAS, PATRICK COUGARD, BÉATRICE CHAMBE, \\ CORINNE MONTVERNAY, ALAIN CALENDER, AND THE MEMBERS OF GROUPE D'Etude DEs Néoplasies \\ EndoCRINIENNES MulTIPLES*
}

Department of Endocrinology (B.V., F.B.), University Hospital, 21000 Dijon, France; Department of Surgery (P.G., P.C.), University Hospital, 21000 Dijon, France; Department of Endocrinology (A.M.), University Hospital, 44000 Nantes, France; Department of Endocrinology (A.B.), Sart Tilman University, 4000 Liège, Belgium; Department of Nuclear Medicine (G.S.), Hôpital Neuro-Cardiologique, 69000 Lyon, France; and Laboratory of Genetics (B.C., C.M., A.C.), Hôpital Edouard Herriot, 69437 Lyon, France

To date, data on pituitary adenomas in MEN type 1 (MEN1) still have to be evaluated. We analyzed the data of a large series of 324 MEN1 patients from a French and Belgian multicenter study. Data on pituitary disease were compared with those from 110 non-MEN1 patients with pituitary adenomas, matched for age, year of diagnosis, and follow-up period. Genetic analysis of the MEN1 gene was performed in 197 of the MEN1 patients. In our MEN1 series, pituitary disease occurred in 136 of $324(42 \%)$, less frequently than hyperparathyroidism $(95 \%, P<0.001)$ and endocrine enteropancreatic tumors $(54 \%, P<0.01)$. Mean age of onset of pituitary tumors was $38.0 \pm 15.3 \mathrm{yr}$ (range, 12-83 yr). Pituitary disease was associated with hyperparathyroidism in $90 \%$ of cases, with enteropancreatic tumors in $47 \%$, with adrenal tumors in $16 \%$, and with thoracic neuroendocrine tumors in $4 \%$. Pituitary disease was the initial lesion of MEN1 in $17 \%$ of all MEN1 patients. MEN1 pituitary adenomas were significantly more frequent in women than in men $(50 \%$ vs. $31 \%, P<0.001)$. Among the 136 pituitary adenomas, there were 85 prolactinomas and 12 GH-secreting, 6 ACTH-secreting, 13 cosecreting, and 20 nonsecreting tumors. Eighty-five percent of MEN1-related pituitary lesions were macroadenomas (vs. $42 \%$ in non-MEN1 patients, $P<0.001$ ), including $32 \%$ of invasive cases. Among secreting adenomas, hormonal hypersecretion was normalized, after treatment, in only $42 \%$ (vs. $90 \%$ in non-MEN1 patients, $P<0.001$ ), with a median follow-up of $11.4 \mathrm{yr}$. No correlation was found between the type of $M E N 1$ germ-line mutation and the presence or absence of pituitary adenoma.

Our study, based on a large group of MEN1 patients, shows that pituitary adenomas occur in $42 \%$ of the cases and are characterized by a larger size and a more aggressive presentation than without MEN1. (J Clin Endocrinol Metab 87: 457-465, 2002)
$\mathrm{M}$ ULTIPLE ENDOCRINE NEOPLASIA type 1 (MEN1) is an inherited disease predisposing to primary hyperparathyroidism, endocrine enteropancreatic tumors, pituitary adenomas, adrenocortical and thymic/bronchial neuroendocrine tumors (1-4). Most cases occur with a familial history of MEN1, but sporadic cases of MEN1 are now frequently encountered. MEN1 is related to mutations in MEN1, an approximately $10-\mathrm{kb}$ gene encoding menin, localized to chromosome 11q13 (5-7). The reported prevalence of pituitary adenomas in MEN1 is between $15 \%$ and 50\% (4, 8-14). This wide range of prevalence values might be related to differences in technical procedures of the different studies and mostly limited number of patients included in each of them (9-11). Moreover, results of prior studies based on single large MEN1 families require confirmation $(2,13)$. To date, very little is known about the size, the outcome, and the response to therapy of MEN1-related pituitary adenomas. Thus, to get further insight into pituitary disease in MEN1, we analyzed the data on pituitary adenomas, in a very large group of 324 patients with MEN1 from a French-Belgian multicenter clinical network, the GENEM (Groupe d'Etude

Abbreviations: GENEM, Groupe d'Etude des Néoplasies Endocriniennes Multiples; HD, heteroduplex; MEN1, MEN type 1. des Néoplasies Endocriniennes Multiples) $(15,16)$. The aim of our study was to clarify data on pituitary disease in MEN1.

\section{Subjects and Methods}

\section{Patients}

We analyzed the 324 MEN1 cases collected through the GENEM registry and belonging to 22 distinct clinical centers in France and Belgium. The diagnosis of MEN1 was assessed in patients presenting at least 2 out of 3 major MEN1 lesions (hyperparathyroidism, endocrine enteropancreatic, or anterior pituitary tumors), including both those with and without MEN1 germline mutation. Diagnosis of MEN1 was also assessed in patients with a unique major MEN1 lesion and sharing MEN1 germline mutations. Among the 324 MEN1 cases collected in our registry, a genetic diagnosis was performed in 197 patients ( 167 familial cases from 62 families and 30 from sporadic cases, representing 92 probands) and in related cases of their family, by heteroduplex (HD) analysis of MEN1 exons and introns and further sequencing of abnormal sequences by HD analysis. When HD analysis was negative, the full $M E N 1$ sequence was analyzed as previously described (15). Families with a common ancestor were considered as a single family. Most of the mutations identified in the French series of MEN1 patients were reported in the mutation database included in the GENEM website (http://rockefeller1.univ-lyon1.fr/GENEM/new/database.html or http://umd2.necker.fr: 2006/) based on UMD software (17). All known affected members of each family were included. The study was approved by the ethics committee of Lyon University Hospital, and genetic studies have been performed after informed consent of each patient, according to French laws. 


\section{Epidemiological methods}

For each patient, data on the multiple endocrine neoplasia were recorded on a file including 164 items. When data were missing or considered as imprecise, an additional query form was sent to the physician in charge of the patient. Age of onset for a feature was the age at the time of diagnosis for this feature. The diagnosis of pituitary lesion was made on radiological data. Diagnosis of secreting pituitary adenoma was made on increased plasma levels of pituitary hormones (PRL, $\mathrm{GH}, \mathrm{ACTH})$. Histopathological data were obtained in 50 patients (among the 61 subjects who underwent pituitary surgery); and in 42 of them, immunohistochemistry data were available. Pituitary adenomas were classified according to their size, using the Hardy classification (18). Tumors were classified as microadenomas (grade I) when less than $10 \mathrm{~mm}$ in diameter, and as macroadenomas (grades II, III, and IV) when equal or greater than $10 \mathrm{~mm}$ in diameter. Grade III (local invasion) and Grade IV (diffuse invasion) macroadenomas were considered as invasive tumors (18).

\section{Control group}

Data obtained in MEN 1 patients were compared with those from 110 non-MEN1 patients with pituitary adenomas. These control subjects were randomly selected among a list of patients followed for non-MEN1 pituitary tumors in the different endocrinology departments of the GENEM network. The random selection of the controls matched for age, year of diagnosis, and follow-up period was performed with software from SPSS, Inc., Chicago, IL. Each control subject had no other endocrine lesion than the pituitary tumor and no family history of multiple endocrine neoplasia. No control subject had MEN1 mutation testing.

\section{Statistical methods}

Results are expressed as mean \pm SD. For quantitative data, comparisons were made by using the $t$ test and ANOVA when comparing two or several groups of patients, respectively. For qualitative data, comparisons between groups were based on the chi-square test. Logistic regression analysis was performed using the SPSS, Inc. software. Odds ratio ranges are given with $95 \%$ confidence limit.

\section{Results}

Frequency, age, and sex distribution of pituitary disease in MEN1

The distribution of the different endocrine lesions, among the 324 MEN1 patients, is shown in Fig. 1. Among the 324 MEN1 patients, 136 (42\%) had pituitary adenomas and 174 (54\%) presented endocrine enteropancreatic tumors. Most MEN1 patients (308) were affected by hyperparathyroidism $(95 \%)$. Adrenal tumors were found in 54 patients $(17 \%)$, and thymic or bronchial neuroendocrine tumors in 25 patients $(8 \%)$. The types of enteropancreatic tumors were not different between MEN1 patients with or without pituitary disease. The mean age of onset of pituitary disease (38.0 \pm 15.3 yr) was not significantly different from that of hyperparathyroidism (39.4 $\pm 14.1 \mathrm{yr})$ or enteropancreatic lesions $(40.8 \pm 14.0 \mathrm{yr})$. The age-related penetrance curve of pituitary adenomas in MEN1 is shown in Fig. 2A. The age of onset of pituitary adenomas ranged between 12-83 yr. Twenty five percent of pituitary adenomas were diagnosed before the age of $26 \mathrm{yr}$, and $75 \%$ before the age of $46 \mathrm{yr}$. Among the 136 pituitary adenomas, only 6 had an isolated pituitary lesion. Pituitary adenomas were significantly more frequent in women than in men (50\% vs. $31 \%, P<0.001)$.
FIG. 1. Distribution of the main endocrine lesions (hyperparathyroidism, endocrine enteropancreatic tumors, and pituitary disease) among the 324 MEN1 patients. For each endocrine lesion, the number of cases and the percentage of the affected subjects among the total MEN1 patients are given [308 patients with hyperparathyroidism, 174 with endocrine enteropancreatic tumors, 136 with pituitary adenomas, 54 with adrenal tumors, and 25 with neuroendocrine tumors (thymic or bronchial)]. Adrenal and neuroendocrine tumors are not in the figure. Among the 54 adrenal tumors, 8 are associated with parathyroid adenoma (PTH) alone, 21 are associated with both PTH + enteropancreatic tumor (PAN), 2 with both PTH + pituitary adenoma (PIT), 2 with both PAN + PIT, 16 with PTH + PAN + PIT, 3 with PTH + PAN + neuroendocrine tumor (NEUR), and 2 with PTH + PAN + PIT + NEUR. Among the 25 neuroendocrine tumors, 2 are isolated, 2 are associated with PTH alone, 11 are associated with both PTH + PAN, 1 with both PTH + PIT, 1 with both PTH + adrenal tumor (ADR), 3 with PTH + $\mathrm{PAN}+\mathrm{PIT}, 3$ with $\mathrm{PTH}+\mathrm{PAN}+\mathrm{ADR}$, and 2 with PTH + PAN + PIT + ADR.

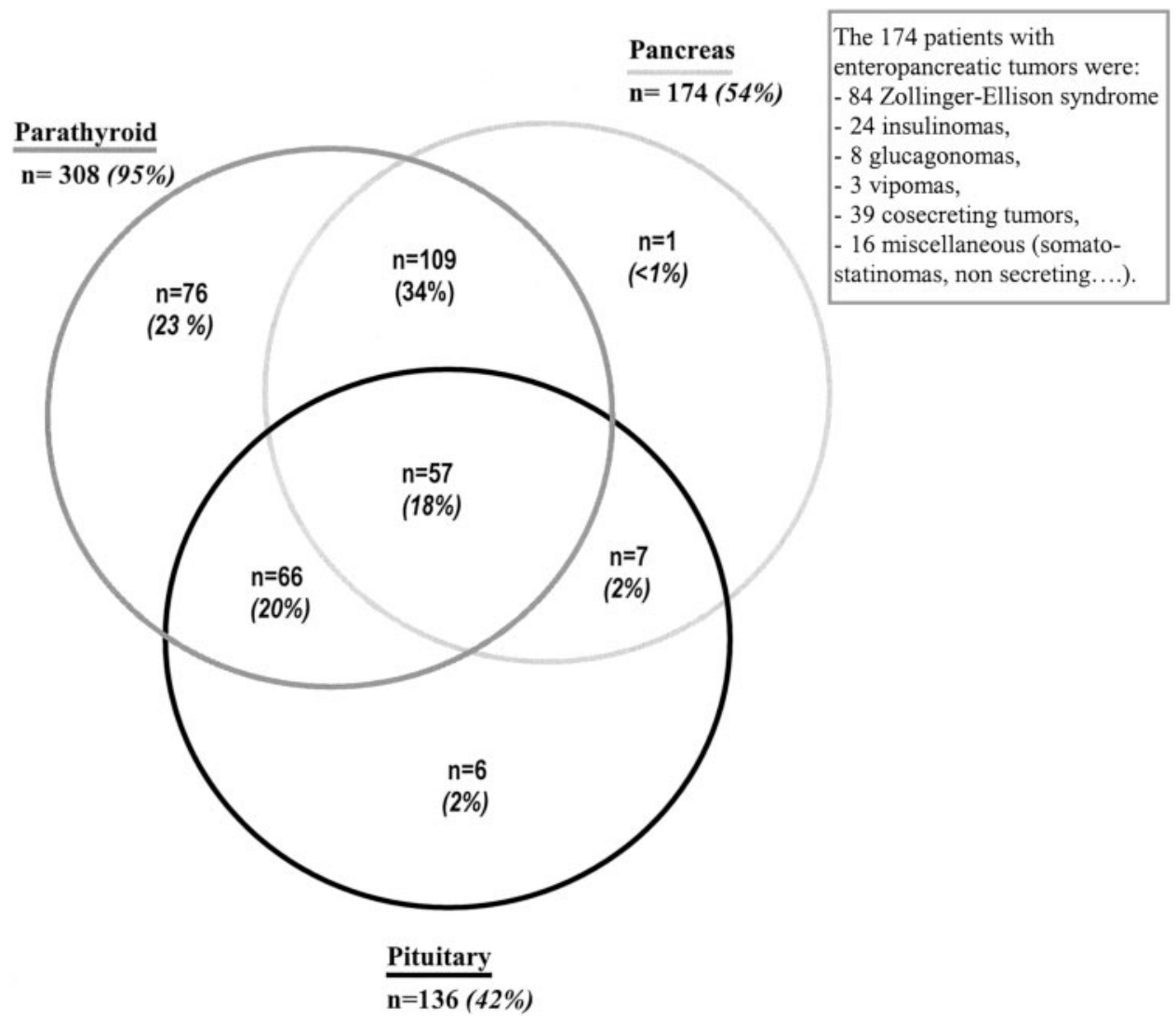




\section{Occurrence of pituitary disease in the course of MEN1}

Among the 136 MEN1 patients with pituitary disease, pituitary adenoma was the initial manifestation of MEN1 in 56 cases (17\% of all MEN1 patients). Thirty-seven of the 136 patients with pituitary disease had concomitantly diagnosis of pituitary adenoma and another endocrine lesion. The mean age of the patients with pituitary disease as initial manifestation of MEN1 (33.9 $\pm 14.0 \mathrm{yr})$ was significantly younger than that of patients showing first an endocrine enteropancreatic tumor $(41.6 \pm 14.0 \mathrm{yr}, P<0.01)$ (Table 1$)$. The mean delay between the initial and the subsequent MEN1 endocrine lesion was significantly longer when pitu- itary disease was the initial MEN1 manifestation $(9.0 \pm 8.1$ $\mathrm{yr})$ than when enteropancreatic tumor $(4.1 \pm 4.0 \mathrm{yr})$ or hyperparathyroidism $(5.2 \pm 5.1 \mathrm{yr})$ were the initial presentation of MEN1 (Table 1). The proportion of MEN1 patients with pituitary disease was 40\% before 1984, 49\% between 1984 and 1994 , and 34\% after 1994. Prevalence of pituitary disease was significantly different among these 3 periods $(P<0.05)$; but, as shown in Fig. 2B, the age-related penetrance curve of pituitary disease was not different among the 3 periods. The diagnosis of MEN1 before the age of $25 \mathrm{yr}$ was significantly more frequent after 1994 (26\%) than before 1994 (11\%) $(P<0.01)$.
Fig. 2. A, Age-related penetrance curve of pituitary adenomas in MEN1 and age-related penetrance curve of MEN1 (age of MEN1 diagnosis). B, Age-related penetrance curve of pituitary adenomas in MEN1 during 3 periods: before 1984, between 1984 and 1994, and after 1994.

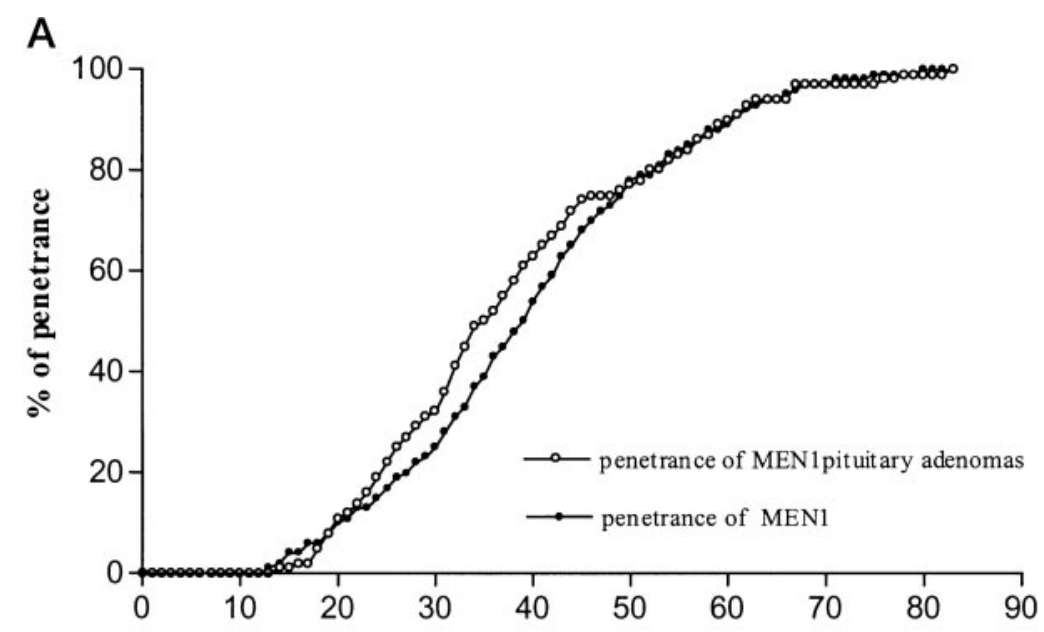

B

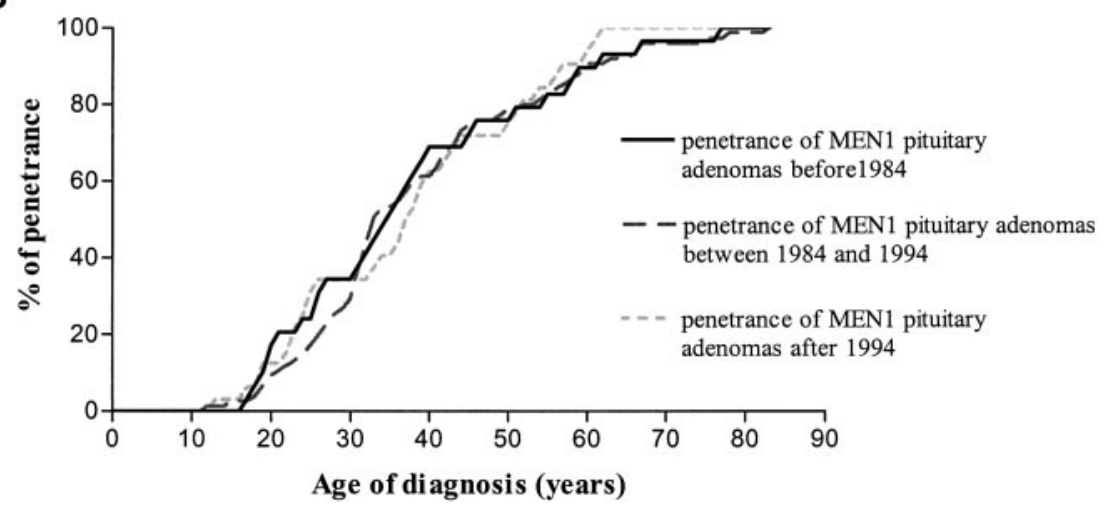

TABLE 1. Mean age (in years) of the initial MEN1 endocrine lesion and mean delay (in years) between the initial and the subsequent MEN1 endocrine lesion for each main endocrine lesion (hyperparathyroidism, enteropancreatic tumor, or pituitary disease) as unique initial manifestation of MEN1

\begin{tabular}{|c|c|c|c|}
\hline & $\begin{array}{l}\text { Hyperparathyroidism } \\
\text { as unique initial } \\
\text { manifestation of MEN1 } \\
\qquad(\mathrm{n}=119)\end{array}$ & $\begin{array}{l}\text { Enteropancreatic } \\
\text { tumor as unique } \\
\text { initial manifestation } \\
\text { of MEN1 }(\mathrm{n}=63)\end{array}$ & $\begin{array}{l}\text { Pituitary disease as } \\
\text { unique initial } \\
\text { manifestation of } \\
\text { MEN1 }(\mathrm{n}=56)\end{array}$ \\
\hline $\begin{array}{l}\text { Age of the initial MEN1 endocrine } \\
\text { lesion (yr) }\end{array}$ & $35.0 \pm 14.4^{a}$ & $41.6 \pm 14.0^{a, b}$ & $33.9 \pm 14.0^{b}$ \\
\hline $\begin{array}{l}\text { Delay between the initial and the } \\
\text { subsequent MEN1 endocrine } \\
\text { lesion (yr) }\end{array}$ & $5.2 \pm 5.1^{c}$ & $4.1 \pm 4.0^{d}$ & $9.0 \pm 8.1^{c, d}$ \\
\hline
\end{tabular}

${ }^{a}$ Hyperparathyroidism vs. pancreatic tumor, $P<0.01$.

${ }^{b}$ Pituitary disease $v s$. pancreatic tumor, $P<0.01$.

${ }^{c}$ Pituitary disease $v s$. hyperparathyroidism, $P<0.001$.

${ }^{d}$ Pituitary disease $v s$. pancreatic tumor, $P<0.001$. 


\section{Pituitary disease in familial and sporadic MEN1}

Among the 136 MEN1 patients with pituitary disease, 75 were familial and 61 sporadic. Prevalence of pituitary disease was significantly higher in sporadic MEN1 patients than in familial MEN1 subjects (59\% vs. 34\%, $P<0.001$ ). However, among MEN1 patients with at least 2 organs affected, prevalence of pituitary adenomas between sporadic (59\%) and familial $(47 \%)$ cases was not statistically different.

\section{Search for criteria predisposing to pituitary disease}

Factors related to the risk of occurrence of pituitary adenoma in MEN1 were searched by multivariate analysis using a multiple logistic regression model. Criteria included were sex, age at time of diagnosis, sporadic or familial case, time of MEN1 diagnosis, onset of death during the follow-up period, and presence of adrenal and/or thymic/bronchial neuroendocrine tumors. Sporadic occurrence of MEN1 [odds ratio: 1.67 (range, $1.29-2.17$ ), $P<0.001$ ] and female sex [odds ratio: 1.42 (range, 1.11-1.82), $P<0.01$ ] were independently associated with an increased prevalence of pituitary disease, whereas other criteria were not. When the multivariate analysis was performed in MEN1 patients with at least two organs affected, only the female sex was associated with prevalence of pituitary adenoma in MEN1 [odds ratio: 1.50 (range, 1.30-1.71), $P<0.01]$.

\section{Type of pituitary adenomas}

Among the 136 pituitary adenomas, 85 were prolactinomas $(62 \%), 12$ were $\mathrm{GH}$-secreting adenomas (9\%), 6 produced ACTH (4\%), and 13 (5 PRL + GH; 2 PRL + FSH; 4 PRL + ACTH, 1 PRL $+\alpha$-subunit, and $1 \mathrm{GH}+\alpha$-subunit) were cosecreting adenomas (10\%) (Table 2). Twenty of the 136 cases were nonsecreting (15\%); and in 2 of 15 nonsecreting adenomas histologically examined, immunohistochemistry was positive for LH and FSH. Eighty-six patients presented clinical manifestations related to pituitary hypersecretion (Table 2). Thirty-nine patients (29\%) had clinical manifestations related to the size of the pituitary adenoma (headache alone in 5 patients, visual defects alone in 22, and both in 12). Mean age of patients with prolactinomas was significantly younger than that of other types of pituitary adenomas (35.1 \pm 14.8 vs. $43.8 \pm 14.4 \mathrm{yr}, P<0.001)$. No differences were shown among the different types of pituitary adenomas by comparing sex distribution, sporadic and familial MEN1, and the time of occurrence in the course of MEN1. As far as prolactinomas were concerned, there were no significant differences between men and women for age at diagnosis, size of the adenoma, and time of occurrence in the course of MEN1.

\section{Size of pituitary adenomas}

Among the 136 pituitary lesions, 19 were microadenomas $(14 \%)$, and 116 were macroadenomas (85\%), including 43 invasive macroadenomas (grades III and IV from Hardy classification). All the GH and nonsecreting tumors were macroadenomas (including, respectively, 8 and 10 invasive tumors). Among the 85 prolactinomas, 71 were macroadenomas (84\%), including 20 invasive tumors. Among the 6

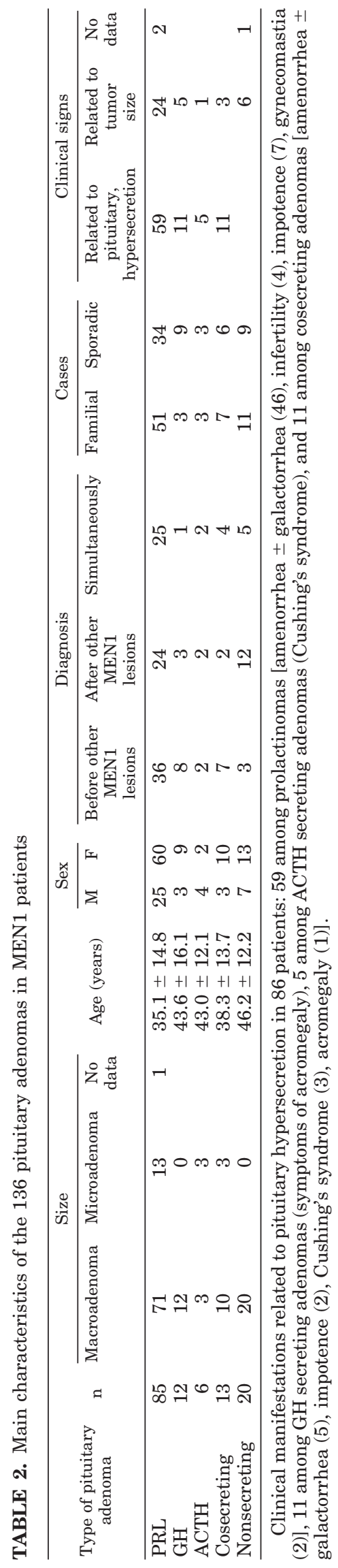


ACTH-secreting adenomas, 3 were macroadenomas (50\%), including 1 invasive tumor. Among the 13 cosecreting adenomas, 10 were macroadenomas (77\%), including 4 invasive tumors (Table 2). The frequency of macroadenomas was not different between familial and sporadic MEN1 and among age-quartiles. The proportion of pituitary microadenomas was not statistically different between patients diagnosed before 1994 (14\%) and those diagnosed after 1994 (16\%).

\section{Outcome of pituitary adenomas}

Various therapeutic strategies used in our series are shown in Table 3. Each patient was treated optimally in 1 of the 22 multidisciplinary centers from the GENEM sharing similar updated protocols. The median follow-up period for all the MEN1 pituitary adenomas was 11.4 yr (range, 0-47.9 yr). During this follow-up period, death occurred in 4 patients and was directly related to the pituitary lesion in only 1 patient. As far as the 116 patients with pituitary secreting adenomas were concerned, normalization of the pituitary hypersecretion occurred, on treatment, in 49 patients (42\%), hormonal hypersecretion persisted in 53 (46\%), and hypopituitarism developed after treatment in 8 patients $(7 \%)$. No data concerning the outcome were available for 6 of the patients (Table 3). Normalization of pituitary hypersecretion occurred in $56 \%$ of patients with grade I or II tumor size and only in $33 \%$ of patients with grade III or IV tumor size $(P<$ 0.05). Among the 85 prolactinomas, plasma PRL levels were normalized in only 37 patients $(44 \%)$.

\section{Comparison with non-MEN1 pituitary adenomas}

Data obtained in MEN 1 patients were compared with those from 110 non-MEN1 patients with pituitary adenomas matched for age, year of diagnosis, and follow-up period. As shown in Table 4, the distribution of the types of pituitary adenomas was not significantly different between the 2 groups. The frequency of macroadenomas was significantly higher in MEN1 patients than in non-MEN1 subjects $(85 \%$ vs. $42 \%, P<0.001)$. Clinical manifestations related to the size of the pituitary adenoma (headache, visual defects) were significantly more frequent in MEN1 patients than in nonMEN1 subjects $(29 \%$ vs. $14 \%, P<0.01)$. As far as the secreting pituitary adenomas were concerned, normalization of pituitary hypersecretion was much less frequent in MEN1 patients than in non-MEN1 subjects $(42 \%$ vs. $90 \%, P<0.001)$ (Table 4). Macroprolactinomas were more frequent in MEN1 patients than in non-MEN1 subjects ( $84 \%$ vs. $24 \%, P<0.001)$, and normalization of plasma PRL level was significantly less frequent in MEN1 patients than in non-MEN1 subjects $(44 \%$ vs. $90 \%, P<0.001)$.

\section{Genetic analysis}

Among the 197 MEN1 patients (167 familial cases and 30 sporadic cases) who had genetic analysis of the MEN1 gene, germline mutations of the MEN1 gene were found in 150, and a large $M E N 1$ germline deletion in 25 patients from a single family (Lespinasse et al., submitted). In 22 patients, we did

TABLE 3. Treatment of the pituitary adenomas in MEN1 patients and outcome

\begin{tabular}{|c|c|c|c|c|c|c|c|c|c|c|}
\hline & \multirow[b]{2}{*}{$\mathrm{n}$} & \multicolumn{4}{|c|}{ Treatment (alone or combined) } & \multirow[b]{2}{*}{$\begin{array}{l}\text { Median } \\
\text { follow-up } \\
\text { (years) }\end{array}$} & \multicolumn{4}{|c|}{ Outcome } \\
\hline & & Surgery & Radiotherapy & $\begin{array}{l}\text { Medical } \\
\text { treatment }\end{array}$ & $\begin{array}{l}\text { No } \\
\text { data }\end{array}$ & & $\begin{array}{c}\text { Normalization of } \\
\text { pituitary } \\
\text { hypersecretion }\end{array}$ & $\begin{array}{l}\text { Persisting pituitary } \\
\text { hypersecretion }\end{array}$ & Hypopituitarism & Unknown \\
\hline PRL & 85 & 29 & 8 & 52 & 3 & 12.9 & 37 & 37 & 6 & 5 \\
\hline $\mathrm{GH}$ & 12 & 8 & 5 & 3 & & 11.9 & 6 & 4 & 2 & \\
\hline $\mathrm{ACTH}$ & 6 & 4 & 1 & 4 & & 8.9 & 2 & 3 & 0 & 1 \\
\hline Cosecreting & 13 & 6 & 1 & 8 & & 12.9 & 4 & 9 & 0 & \\
\hline Nonsecreting & 20 & 17 & 4 & 1 & & 8.4 & & & 5 & \\
\hline
\end{tabular}

TABLE 4. Pituitary adenomas in MEN1 patients and in controls

\begin{tabular}{|c|c|c|c|}
\hline & $\begin{array}{l}\text { MEN } 1 \text { pituitary adenomas } \\
\qquad(\mathrm{n}=136)\end{array}$ & $\begin{array}{l}\text { Control (non-MEN1) } \\
\text { pituitary adenomas } \\
\quad(\mathrm{n}=110)\end{array}$ & $P$ \\
\hline $\begin{array}{l}\text { Age (yr) } \\
\text { Mean follow-up (yr) }\end{array}$ & $\begin{array}{l}38.0 \pm 15.3 \\
11.1 \pm 8.7\end{array}$ & $\begin{array}{l}36.2 \pm 14.6 \\
10.0 \pm 6.3\end{array}$ & $\begin{array}{l}\text { NS } \\
\text { NS }\end{array}$ \\
\hline $\begin{array}{l}\text { Type of pituitary adenoma: } \\
\text { PRL } \\
\text { GH } \\
\text { ACTH } \\
\text { Cosecreting } \\
\text { Nonsecreting }\end{array}$ & $\begin{array}{l}\mathrm{n}=85 \\
\mathrm{n}=12 \\
\mathrm{n}=6 \\
\mathrm{n}=13 \\
\mathrm{n}=20\end{array}$ & $\left.\begin{array}{l}\mathrm{n}=68 \\
\mathrm{n}=15 \\
\mathrm{n}=7 \\
\mathrm{n}=2 \\
\mathrm{n}=18\end{array}\right\}$ & NS \\
\hline Clinical signs related to tumor size & $\mathrm{n}=39(29 \%)$ & $\mathrm{n}=15(14 \%)$ & $P<0.01$ \\
\hline $\begin{array}{l}\text { Tumor size } \\
\text { Microadenoma } \\
\text { Macroadenoma }\end{array}$ & $\begin{aligned} \mathrm{n} & =19(14 \%) \\
\mathrm{n} & =116(85 \%) \\
\text { no data: } \mathrm{n} & =1(1 \%)\end{aligned}$ & $\left.\begin{array}{l}\mathrm{n}=64(58 \%) \\
\mathrm{n}=46(42 \%)\end{array}\right\}$ & $P<0.001$ \\
\hline $\begin{array}{l}\text { Outcome } \\
\text { Normalization of pituitary hypersecretion }\end{array}$ & $\mathrm{n}=49(42 \%)$ & $\mathrm{n}=83(90 \%)$ & $P<0.001$ \\
\hline
\end{tabular}

For each qualitative data, the number of patients and the percentage of affected patients in each group (MEN1 patients and controls) are given. The results of the statistical comparison between the two groups (MEN1 patients and controls) are shown in the last column. 
not find any MEN1 germline mutations/deletions. A germline mutation/deletion of the MEN1 gene was observed in $63 \%$ of the tested sporadic cases and in $93 \%$ of the tested familial cases. The 167 familial cases belonged to 62 different families. Among these 62 families, a mutation was found in 54 families, a complete deletion in 1 family (with 25 affected members), and no mutation or deletion in 7 families. Nine families sharing the same mutation [respectively, 2 with 359del4 (exon 2), 2 with R98× (exon 2), 2 with R460× (exon 10 ), and 3 with 1650insC/G (exon 10)] were shown to be unrelated, using both 11q13 haplotype analysis and ascendant genealogical evaluation, by techniques which have been previously described (15). The mutations observed in our MEN1 patients and the relative penetrance of pituitary disease for each of them are shown in Fig. 3. No obvious genotype-phenotype correlation was observed, and we considered that no specific types and/or locations of mutations might be significantly correlated with the risk of occurrence of pituitary adenoma in our MEN1 series. No differences were observed, between the 197 MEN1 patients for whom genetic testing has been performed and the 127 patients in which genetic testing was not undertaken, for the frequency of pituitary disease ( $42 \%$ vs. $43 \%$ ), the sex ratio, the distribution of endocrine lesion, the rate of pituitary adenomas as initial lesion of MEN1, the size of the pituitary adenomas, the treatment of pituitary adenomas, and the outcome.

\section{Discussion}

MEN1 has an estimated prevalence of $0.02-0.2$ per 1000 (8). Data on pituitary lesions in MEN1 are uncommon to date, and we consider the present study as the largest one reported so far. In our work including patients from 22 different multidisciplinary centers from the GENEM, in France and Bel-

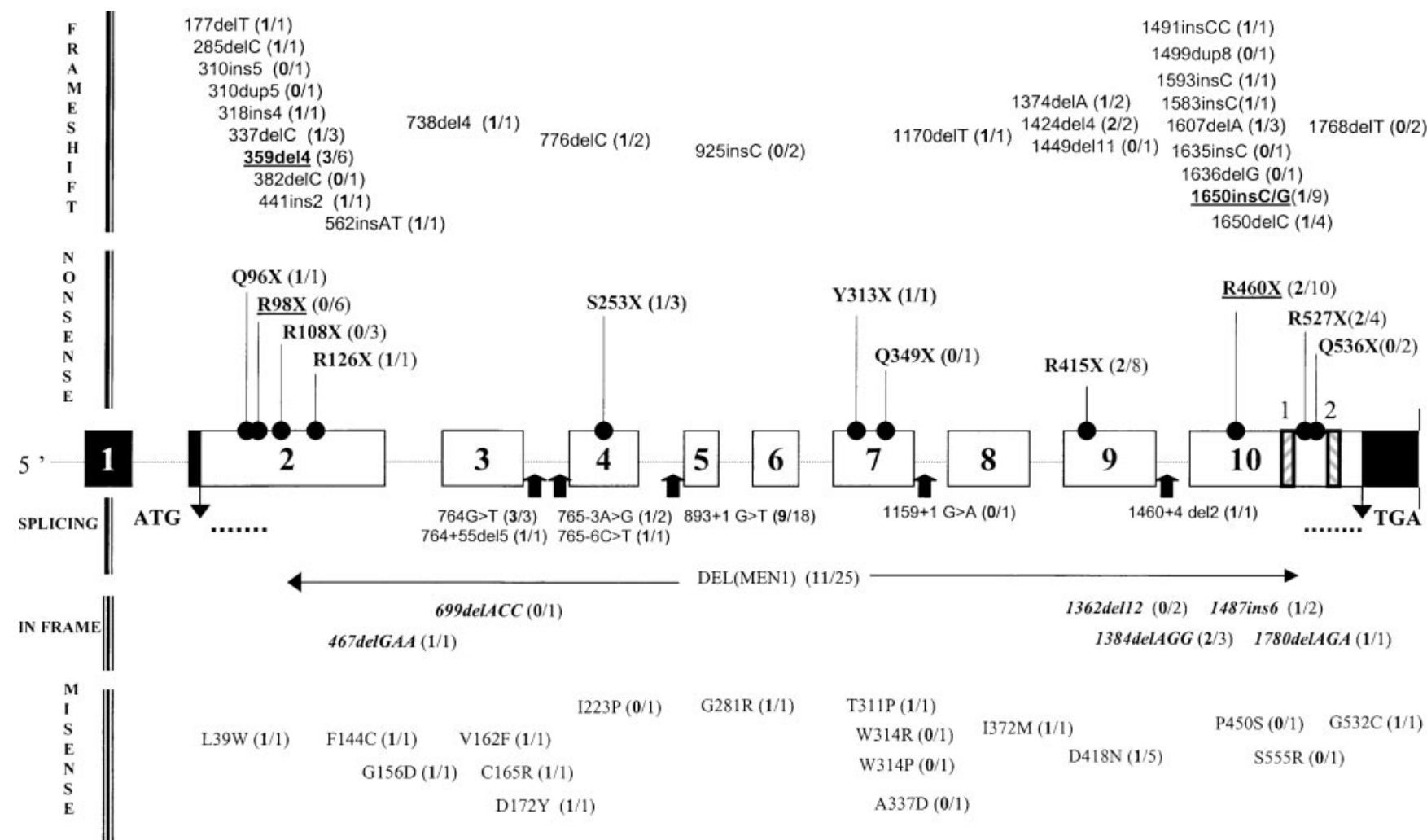

FIG. 3. Detailed overview of MEN1 germline mutations (+ 1 complete gene deletion) and pituitary disease expression found in 156 patients from 55 unrelated MEN1 families and 19 patients with a priori sporadic MEN1 disease. This represents a total number of 68 distinct mutations (49 observed in familial and 19 in sporadic cases). Clear boxes and the numeric numbers inside represent exonic sequences. Intronic regions are summarized by a dotted line. Black boxes (exon 1 and a part of exon 10) represent untranslated regions of the gene. Mutations are approximately localized along the gene and shown using a comprehensive nomenclature system, including reference letters for amino acids (41). For instance, 177delT, a frameshift mutation, indicates deletion of T after nucleotide 177 in exon 2 . R98 $\times$, a nonsense mutation, indicates a premature translation stop at codon 98 by disruption of the arginine $(\mathrm{R})$ coding triplet. For nonsense mutations, the premature translations stop are directly drawn on the coding sequence. Missense mutations are symbolized using the amino acid reference letter and position of the affected codon. In-frame deletions are shown in italic bold characters. Intronic and/or splice site mutations are indicated by an arrow under the gene sequence. ATG and TGA represent menin translation the codon and termination codon, respectively. DEL (MEN1) indicates the full deletion, found in a large MEN1 family, affecting the whole MEN1 coding sequence and adjacent regions (Lespinasse et al., submitted for publication). The first number in parentheses, in bold, indicates the number of patients affected by pituitary disease for each mutations. The second number shows the total number of MEN1 patients in the family sharing the mutation. For instance, the family with a germline 337delC MEN1 mutation is characterized by 1 patient with pituitary lesions among a total of 3 affected, symbolized by (1/3). Last, recurrent mutations are designed by underlined bold characters. Nine families showed 4 common mutations, respectively $(2$ with 359 del 4,2 with R98 $\times, 2$ with R460 $\times$, and 3 with 1650insC/G). For these recurrent mutations, the first number in parentheses indicates the total number of patients affected by pituitary disease, and the second number indicates the total number of MEN1 patients in all unrelated families sharing the common mutation. 
gium, one would expect a reduced recruitment bias, compared with monocentric reports $(10,11,13,19,20)$. Thus, our extensive, multicenter, and multidisciplinary study gives the opportunity to obtain representative and indicative information on pituitary disease in MEN1. Moreover, we have been able to compare the data obtained in MEN 1 patients with those from 110 non-MEN1 patients with pituitary adenomas, matched for age, year of diagnosis, and follow-up period. On the basis of several reports that have shown that MEN1 germline mutation testing was not useful in isolated sporadic pituitary adenomas (21-23), no control subject had MEN1 mutation testing. However, each control subject had no other endocrine lesion than the pituitary tumor at the time of diagnosis, as during the follow-up period, and no family history of multiple endocrine neoplasia, attesting that control subjects were non-MEN1 patients.

Prevalence of pituitary disease among our MEN1 patients was $42 \%$, and this is equivalent or higher than frequencies reported by O'Brien (43\%) (20), Öberg (42\%) (9), Burgess (18\%) (13), Trump (29.5\%) (4), and Skogseid (20\%) (11) and slightly lower than the prevalence rate reported by Marx (14). However, prevalence of pituitary lesions reported by necropsy studies in MEN1 (65\%) suggests that diagnosis of pituitary adenoma may be missed in some patients during the lifetime course of the disease (24). Pituitary disease was the first manifestation of MEN1 in $17 \%$ of our patients, which is in agreement with a previous report (25). The mean delay between the initial and the subsequent MEN1 endocrine lesion is significantly longer when pituitary disease is the initial MEN1 manifestation than when enteropancreatic tumor or hyperparathyroidism is the initial presentation of MEN1. This could be attributable, in part, to the younger age of the patients with pituitary disease as initial manifestation of MEN1, but also to a less frequent consideration of MEN1 diagnosis in patients with pituitary adenomas than in patients with endocrine enteropancreatic tumors or hyperparathyroidism.

We show that MEN1-related pituitary disease may occur at all ages from 12-83 yr. Indeed, pituitary adenomas may be present at an early age, and macroadenomas are as frequent in young as in old patients. This is in agreement with a recent report of an aggressive pituitary adenoma in a 5-yrold boy with familial MEN1 (26). Previous studies suggested that the onset of pituitary disease in MEN1 could not occur after the age of $60 \mathrm{yr}(3,9-11)$. Our results do not support this view and are in agreement with the data reported by Trump et al. (4), who noted that the rate of pituitary adenoma diagnosis in MEN1 was not different below and above $40 \mathrm{yr}$.

Prevalence of pituitary disease among our MEN1 patients was lower before 1984 than during the 1984-1994 period. This increase is likely to be attributable to the wider use of computed tomography and magnetic resonance imaging. After 1994, the pituitary adenoma diagnosis rate is found to be less important. Diagnosis of MEN1 is performed earlier, since 1994, as a consequence of the generalization of genetic analyses. Thus, the higher rate of young MEN1 patients after 1994 is likely to be the main reason for the reduced pituitary adenoma diagnosis rate during this last period of our study. Indeed, as suspected on the age-related penetrance curve, the younger the patients are, the lower the risk to have a diagnosed pituitary adenoma.

The increased female-to-male ratio in MEN1 patients with pituitary adenoma is equivalent to what has been observed for pituitary adenomas in non-MEN1 patients (27). The influence of sex on the prevalence of pituitary disease in MEN1 is not confounded by other factors, as shown in the multivariate analysis. This increased prevalence of pituitary adenomas in women is not explained. However, a role of estrogens could be considered, because there is experimental evidence that estrogens can amplify tumor growth-promoting factors in pituitary cell lines (28). As suggested by our analysis limited to MEN1 patients with at least two endocrine lesions, the higher frequency of pituitary adenomas in sporadic than familial cases, observed in the whole MEN1 population, is likely to be attributable to the bias that sporadic MEN1 cases must, according to the definition, have two or more organs affected to be diagnosed.

Pituitary adenoma in our MEN1 patients was not associated with a specific type of MEN1 gene mutation. Our results confirm previous studies, which did not show any genotype/phenotype correlation in MEN1 (15, 29-31).

Prolactinomas represent about two thirds of the pituitary adenomas in our MEN1 patients and may be considered as the most frequent pituitary lesion in MEN1, confirming previously reported data obtained in a limited number of patients and families $(9,10,13,32)$. According to our results, the high frequency $(85 \%)$ of pituitary macroadenomas seems to be an important feature of pituitary disease in MEN1. Because most of our MEN1 patients were symptomatic, we cannot completely exclude the possibility that some asymptomatic and small pituitary tumors have been missed in some families. However, after 1994, despite an earlier age of MEN1 diagnosis and a more developed MEN1 family screening, the proportion of pituitary microadenomas was not different than before 1994, suggesting that the number of missed asymptomatic and small pituitary tumors is likely to be very small. This prevalence of macroadenomas is significantly higher than in our control non-MEN 1 group. Our data point out the high prevalence (84\%) of macroadenomas in MEN1related prolactinomas, compared with those observed in non-MEN1 patients, from our study $(24 \%)$, as from the literature $(<30 \%)(33,34)$. The increased prevalence of invasive macroadenomas in MEN1 suggests that pituitary tumors might be more proliferative in MEN1 patients than in nonMEN1 patients.

In previous studies, prolactinomas in MEN1 have been considered comparable, in both clinical behavior and response to treatment, to those occurring in non-MEN1 patients $(10,35)$. However, our data, as those of Burgess (36), suggest a more aggressive natural history of prolactinomas in MEN1. Indeed, we show that prolactinomas in MEN1 are characterized by a larger size but also by a worse response to therapy. Thus, our data suggest that prolactinomas in MEN1 may be more aggressive than those occurring in nonMEN1 patients.

In our series, treatment of pituitary adenomas had a higher success rate at earlier tumor stages. Moreover, several studies have shown that the control of pituitary secreting adenomas 
is more frequent in microadenomas $(80-90 \%)$ than in macroadenomas $(60-75 \%)(37-40)$. Thus, it seems reasonable to recommend earlier diagnosis of pituitary adenomas in MEN1, to increase the rate of control of pituitary secreting adenomas.

In conclusion, pituitary disease is a major component of MEN1; and we show, based on a large population study, that it occurs in $42 \%$ of the MEN1 patients. The majority of pituitary adenomas are prolactinomas. Compared with pituitary adenomas in the non-MEN1 population, pituitary lesions in MEN1 are characterized by a higher frequency of macroadenomas and a worse response to treatment. This suggests that pituitary adenomas in MEN1 may be more aggressive than those occurring in the non-MEN1 patients.

\section{Acknowledgments}

Clinical and genetic studies on MEN1 were performed in the GENEM.

Received June 27, 2000. Accepted September 29, 2001.

Address all correspondence and requests for reprints to: Bruno Vergès, Service d'Endocrinologie, Hôpital du Bocage, 2, bd Mal de Lattre de Tassigny, B. P. 1542, 21034 Dijon Cedex, France. E-mail: bruno.verges@ chu-dijon.fr.

This work was supported by grants from the Ministère de la Santé (PHRC 97-048-Hospices Civils de Lyon) and a research contract from the Association pour le Recherche contre le Cancer (ARC no. 9211).

Coauthors of the GENEM network are: L. Baldet, C. Bauters, J. P. Bercovivi, N. Berger, G. Cadiot, B. Carnaille, P. Caron, O. Chabre, G. Chabrier, P. Chanson, Y. Chapuis, J. A. Chayvialle, J. P. Chigot, B. Conte-Delvox, C. Corcuff, P. Cubertafond, M. Delcoux, B. Delemer, G. De Micco, A. Denizot, D. Dewailly, P. Emy, J. P. Flament, J. M. Guliana, P. Hamon, B. Hamon, A. Hubens, J. F. Henry, P. Jaquet, D. Jaeck, P. Jais, J. L. Kraimps, J. M. Kuhn, J. D. Lalau, M. F. Le Bodic, P. Lecomte, M. Lecomte-Houcke, J. C. Le Neel, F. Leprat, J. Lespinasse, G. Mantion, T. Marmousez, M. Meurisse, M. Mignon, E. Modigliani, P. Nicolli-Sire, M. Parneix, C. Partensky, V. Pascal, F. Pattou, J. L. Peix, F. Penformis, N. Porchet, C. Proye, J. P. Riou, M. Rodier, P. Roger, J. L. Sadoul, J. P. Saint-André, G. Samama, E. Sarfati, M. Schlumberger, F. Schillo, A. Tabarin, J. Tourniaire, J. Trouillas, J. Visset, C. Waterlot, J. L. Wemeau, and N. Wion-Barbot.

\section{References}

1. Werner P 1964 Endocrine adenomatosis and peptic ulcer in a large kindred. Am J Med 35:205-212

2. Majewski JT, Wilson SD 1979 The MeEA-I syndrome: an all or none phenomenon? Surgery 86:475-484

3. Shepherd JJ 1991 The Natural history of multiple endocrine neoplasia type 1. Highly uncommon or highly unrecognized? Arch Surg 126:935-952

4. Trump D, Farren B, Wooding C, Pang JT, Besser GM, Buchanan KD, Edwards CR, Heath DA, Jackson CE, Jansen S, Lips K, Monson JP, O'Halloran D, Sampson J, Shalet SM, Wheeler MH, Zink A, Thakker RV 1996 Clinical studies of multiple endocrine neoplasia type 1 (MEN1). Q J Med 89:653-669

5. Chandrasekharappa SC, Guru SC Manickam P 1997 Positional cloning of the gene for multiple endocrine neoplasia-type 1. Science 276:404-407

6. The European Consortium on MEN1 1997 Identification of the multiple endocrine neoplasia type 1 (MEN1) gene. Hum Mol Genet 6:1177-1183

7. Agarwal SK, Kester MB, Debelenko LV, Heppner C, Emmert-Buck MR, Skarulis MC, Doppman JL, Kim YS, Lubensky IA, Zhuang Z, Green JS, Guru SC, Manickam P, Olufemi SE, Liotta LA, Chandrasekharappa SC, Collins FS, Spiegel AM, Burns AL, Marx SJ 1997 Germline mutations of the MEN1 gene in familial multiple endocrine neoplasia type 1 and related states. Hum Mol Genet 6:1169-1175

8. Brandi ML, Marx SJ, Aurbach GD, Fitzpatrick LA 1987 Familial multiple endocrine neoplasia type I: a new look at pathophysiology. Endocr Rev 8: 391-405

9. Öberg K, Skogseid B, Eriksson B 1989 Multiple endocrine neoplasia type 1 (MEN-1). Clinical, biochemical and genetical investigations. Acta Oncol 28: 383-387

10. Samaan NA, Ouais S, Ordonez NG, Choksi UA, Sellin RV, Hickey RC 1989
Multiple endocrine syndrome type 1. Clinical, laboratory findings, and management in five families. Cancer 64:741-752

11. Skogseid B, Eriksson B, Lundqvist G, Lorelius LE, Rastad J, Wide L, Akerstrom G, Oberg K 1991 Multiple endocrine neoplasia type 1: a 10-year prospective screening study in four kindreds. J Clin Endocrinol Metab 73: 281-287

12. Capella C, Riva C, Leutner M, La Rosa S 1995 Pituitary lesions in multiple endocrine neoplasia syndrome (MENS) type 1. Pathol Res Pract 191:343-347

13. Burgess JR, Shepherd JJ, Parameswaran V, Hoffman L, Greenaway TM 1996 Spectrum of pituitary disease in multiple endocrine neoplasia type 1 (MEN1): clinical, biochemical, and radiological features of pituitary disease in a large MEN1 kindred. J Clin Endocrinol Metab 81:2642-2646

14. Marx S, Spiegel AM, Skarulis MC, Doppman JL, Collins FS, Liotta LA 1998 Multiple endocrine neoplasia type 1: clinical and genetic topics. Ann Intern Med 129:484-494

15. Giraud S, Zhang CX, Serova-Sinilnikova O, Wautot V, Salandre J, Buisson N, Waterlot C, Bauters C, Porchet N, Aubert JP, Emy P, Cadiot G, Delemer B, Chabre O, Niccoli P, Leprat F, Duron F, Emperauger B, Cougard P, Goudet P, Sarfati E, Riou JP, Guichard S, Rodier M, Calender A 1998 Germ-line mutation analysis in patients with multiple endocrine neoplasia type 1 and related disorders. Am J Hum Genet 63:455-467

16. Chanson P, Cadiot G, Murat A 1997 Management of patients and subjects at risk for multiple endocrine neoplasia type 1: MEN1. GENEM 1. Groupe d'Etude des Néoplasies Endocriniennes Multiples de type 1. Horm Res 47: 211-220

17. Beroud C, Collod-Beroud G, Boileau C, Soussi T, Junien C 2000 UMD (Universal Mutation Database): a generic software to build and analyze locusspecific databases. Hum Mutat 15:86-94

18. Hardy J 1973Transphenoidal surgery of hypersecreting pituitary tumors. In: Kholer PO, Ross GT, eds. Diagnosis and treatment of pituitary tumors. New York: Elsevier Publishing Co, Inc; 179-194

19. Scheithauer BW, Laws ER, Kovacs K, Horvath E, Randall RV, Carney JA 1987 Pituitary adenomas of the multiple endocrine neoplasia type I syndrome. Semin Diagn Pathol 4:205-211

20. O'Brien T, O'Riordan DS, Gharib H, Scheithauer BW, Ebersold MJ, Van Heerden J 1996 Results of treatment of pituitary disease in multiple endocrine neoplasia, type 1 . Neurosurgery 39:273-279

21. Zhuang Z, Ezzat SZ, Vortmeyer AO, Weil R, Oldfield EH, Park WS, Pack S, Huang S, Agarwal SK, Guru SC, Manickam P, Debelenko LV, Kester MB, Olufemi SE, Heppner C, Crabtree JS, Burns AL, Spiegel AM, Marx SJ, Chandrasekharappa SC, Collins FS, Emmert-Buck MR, Liotta LA, Asa SL, Lubensky IA 1997 Mutations of the MEN1 tumor suppressor gene in pituitary tumors. Cancer Res 57:5446-5451

22. Prezant TR, Levine J, Melmed S 1998 Molecular characterization of the MEN1 tumor suppressor gene in sporadic pituitary tumors. J Clin Endocrinol Metab 83:1388-1391

23. Farrell WE, Simpson DJ, Bicknell J, Magnay JL, Kyrodimou E, Thakker RV Clayton RN 1999 Sequence analysis and transcript expression of the MEN1 gene in sporadic pituitary tumors. Br J Cancer 80:44-50

24. Ballard HS, Frame B, Hartsock RS 1964 Familial multiple endocrine adenomapeptic ulcer complex. Medicine (Baltimore) 43:481-516

25. Carty SE, Helm AK, Amico JA, Clarke MR, Foley TP, Watson CG, Mulvihill JJ 1998 The variable penetrance and spectrum of manifestations of multiple nedocrine neoplasia type 1 . Surgery 124:1106-1114

26. Stratakis CA, Schussheim DH, Freedman SM, Keil MF, Pack SD, Agarwal SK, Skarulis MC, Weil RJ, Lubensky IA, Zhuang Z, Oldfield EH, Marx SJ 2000 Pituitary macroadenoma in a 5-year-old: an early expression of multiple endocrine neoplasia type 1. J Clin Endocrinol Metab 85:4776-4780

27. Faglia G 1993 Epidemiology and pathogenesis of pituitary adenomas. Acta Endocrinol 129:1-5

28. Llyod RV, Jin L, Fields K, Kulig E 1991 Effects of estrogens on pituitary cell and pituitary tumor growth. Pathol Res Pract 187:584-586

29. Agarwal SK, Kester MB, Debelenko LV, Heppner C, Emmert-Buck MR, Skarulis MC, Doppman JL, Kim YS, Lubensky IA, Zhuang Z, Green JS, Guru SC, Manickam P, Olufemi SE, Liotta LA, Chandrasekharappa SC, Collins FS, Spiegel AM, Burns AL, Marx SJ 1997 Germline mutations of the MEN1 gene in familial multiple endocrine neoplasia type 1 and related states. Hum Mol Genet 6:1169-1175

30. Bassett JH, Forbes SA, Pannett AA, Lloyd SE, Christie PT, Wooding C, Harding B, Besser GM, Edwards CR, Monson JP, Sampson J, Wass JA, Wheeler MH, Thakker RV 1998 Characterization of mutations in patients with multiple endocrine neoplasia type 1. Am J Hum Genet 62:232-244

31. Tanaka C, Yoshimoto K, Yamada S, Nishioka H, Ii S, Moritani M, Yamaoka T, Itakura M 1998 Absence of germ-line mutations of the multiple endocrine neoplasia type 1 (MEN1) gene in familial pituitary adenoma in contrast to MEN1 in Japanese. J Clin Endocrinol Metab 83:960-965

32. Corbetta S, Pizzocaro A, Peracchi M, Beck-Peccoz P, Faglia G, Spada A 1997 Multiple endocrine neoplasia type 1 in patients with recognized pituitary tumours of different types. Clin Endocrinol (Oxf) 47:507-512 
33. Koppelman MCS, Jaffe MJ, Rieth KG, Caruso RC, Loriaux DL 1984 Hyperprolactinemia, amenorrhea, and galactorrhea. A retrospective assessment of twenty-five cases. Ann Intern Med 100:115-121

34. Molitch ME 1995 Prolactinoma. In: Melmed S. ed. Cambridge: Blackwell Science Inc; 443-477

35. McCutcheon IE 1994 Management of individual tumor syndromes-pituitary neoplasia. Endocrinol Metab Clin North Am 1:37-51

36. Burgess JR, Shepperd JJ, Parameswaran V, Hoffman L, Greenaway TM 1996 Prolactinomas in a large kindred with multiple endocrine neoplasia type 1: clinical features and inheritance pattern. J Clin Endocrinol Metab 81:1841-1845
37. Colao A, Annunziato L, Lombardi G 1998 Treatment of prolactinomas. Ann Med 30:452-459

38. Webster J 1999 Clinical management of prolactinomas. Baillieres Best Pract Res Clin Endocrinology Metab 13:395-408

39. Orrego JJ, Barkan AL 2000 Pituitary disorders. Drug treatment options. Drugs 59:93-106

40. Pinzone JJ, Katznelson L, Danila DC, Pauler DK, Miller CS, Klibanski A 2000 Primary medical therapy of micro- and macroprolactinomas in men. J Clin Endocrinol Metab 85:3053-3057

41. Antonarakis SE 1998 Recommendations for a nomenclature system for human gene mutations. Nomenclature Working Group. Hum Mutat 11:1-3 